Jurnal Ekonomi Balance Fakultas Ekonomi Dan Bisnis

Volume 12 No 2 Tahun 2016

\title{
ANALISIS RASIO LIKUIDITAS BERBASIS ARUS KAS PADA PT. MENARA PHINISI HOTELINDO KOTA MAKASSAR
}

\author{
Samsul Rizal ${ }^{1}$ MUSDALIPAH. B $^{2}$ \\ Program Studi Manajemen Fakultas Ekonomi Dan Bisnis \\ Universitas Muhammadiyah Makassar \\ (Musdalipah12345@gmail.com)
}

\begin{abstract}
Musadlipah. B, in 2018 the analysis of cash flow-based liquidity ratio at PT. Phinisi Tower Hotelindo Makassar city, a thesis of faculty management program of economics and business of university muhammadiyah mentor I IdhamKhalik and mentor II Sri Andayaningsih. The purpose of this study is to determine the effect of liquidity and profit on earnings management is related to cash flow from operatioans and accruals. This study encloses financial statements. Then this research use liquidity ratio formula that is current ratio, quick ratio, and cash ratio then cash flow that is activity of operation, activity of invenstasi, and fund activity. It is expected that liquidity profit can predict future cash flow. The results of this study is that there is a significant to cash flow, this shows the ability of the company to pay current liabilies unaffected cash flow. On the contrary, cash flow affects a firm's ability to pay its current liabilities.
\end{abstract}

Kaywords : liquidity ratio and cash flow

\section{ABSTRAK}

Musdalipah. B, Tahun 2018 Analisis Rasio Likuiditas berbasis Arus Kas pada PT. Menara Phinisi Hotelindo kota Makassar, skripsi program studi Manajemen Fakultas Ekonomi dan Bisnis Universitas Muhammadiyah Makassar dibimbing oleh pembimbing Ildham Khalikdan pembimbing II Sri Andayaningsih. Tujuan dari penelitian ini adalah untuk mengetahui pengaruh likuiditas dan keuntungan terhadap memprediksi arus kas masa depan, dan juga melihat indikasi apakah manajemen laba Berkaitan dengan arus kas dari operasi dan akrual terjadi. Penelitian ini melampirkan laporan keuangan. Kemudian penelitian ini menggunakan rumus Rasio Likuiditas yaitu current ratio, quick ratio, dan cash ratio kemudianArus Kas yaitu aktivitas operasi, aktivitas investasi, dan aktivitas pendanaan . Diharapkan Likuiditas dan Profit bisa memprediksi arus kas masa depan. Hasil penelitian ini adalah ada pengaruh yang signifikan terhadap Laba Bersih ke arus kas Ini menunjukkan bahwa tidak ada praktik manajemen laba melalui akrual Tidak ada pengaruh yang signifikan terhadap Rasio Lancar dan Rasio Cepat terhadap Arus Kas, Ini menunjukkan kemampuan perusahaan untuk membayar kewajiban lancar tidak terpengaruh kas mengalir. Sebaliknya, arus kas mempengaruhi kemampuan perusahaan untuk membayar kewajiban lancar.

Kata kunci : Rasio Likuiditas dan Arus Kas 
Jurnal Ekonomi Balance Fakultas Ekonomi Dan Bisnis

Volume 12 No 2 Tahun 2016

\section{PENDAHULUAN}

\section{Latar Belakang}

Hakikat pendirian perusahaan adalah untuk memperoleh profit (keuntungan/laba) yang sebesar-besarnya dari setiap kegiatan usaha yang dijalankan. Berbagai hal dilakukan perusahaan untuk mencapai tujuan tersebut dimana pada umumnya adalah mencari laba dan keuntungan usaha, yang merupakan syarat mutlak dalam menjaling kelangsungan dan perkembangan perusahaan tersebut agar perusahaan dapat tercapai, maka diperlukan adanya suatu rangkaian kerjasama yang teratur dan terintegrasi antara fungsi-fungsi yang terdapat dalam perusahaan. Dengan menganalisis laporan keuangan para analis dapat mengetahui seberapa mampu perusahaan melunasi utang-utangnya terutama utang jangka pendek.

Dalam melakukan analisis laporan keuangan terdapat beberapa rasio yang sering digunakan seperti rasio likuiditas kemampuan perusahaan membayar kewajiban jangka pendeknya. Laporan arus kas menggambarkan perubahaan historis dalam kas dan setara kas yang diklasifikasikan atas aktivitas operasi, invenstasi dan pendanaan selama satu periode yang memberikan imformasi kemungkinan para pengguna untuk mengevaluasi perubahan dalam aset bersih entitas struktur keuangan (likuiditas dan solvabilitas) dan kemampuan mempengaruh jumlah serta waktu arus kas dalam rangka penyusaian terhadap keadaan dan peluang yang berubah. Likuiditas perusahaan menunjukan kemampuan perusahaan dalam melunasi kewajiban jangka pendeknya sebelum tanggal jatuh tempo. Semakin besar jumlah kas yang dimiliki perusahaan maka semakin tinggi pula tingkat likuiditasnya.

Laporan arus kas menjelaskan perubahan pada kas atau setara kas (cash equivalent) dalam periode tertentu. Setara kas adalah investasi jangka pendek yang amat likuid yang bisa segera ditukar dengan kas. Dalam laporan arus kas, penerimaan dan pengeluaran kas diklasifikasikan menurut tiga kategori utama yaitu : aktivitas operasi, aktivitas investasi, aktivitas pendanaan. Likuiditas merupakan kunci utama dalam upaya mempertahankan suatu usaha agar dapat bertahan. Likuiditas juga berarti perusahaan mempunyai cukup dana ditangan untuk 
Jurnal Ekonomi Balance Fakultas Ekonomi Dan Bisnis

Volume 12 No 2 Tahun 2016

membayar tagihan pada saat jatuh tempo dan berjaga-jaga terhadap kebutuhan kas yang tidak terduga. Masalah likuiditas penting dalam menjaga kelancaran operasional perusahaan serta dalam kebutuhan jangka pendek dan darurat serta fungsi pertumbuhan (investasi) untuk mengembangkan asset yang dimiliki sesuai dengan harapan yang diinginkan perusahaan.

Laporan arus kas merupakan suatu laporan yang berguna bagi manajer, investor, kreditur, dan pemakai lainya dimana laporan tersebut dapat memberikan gambaran di perusahaan mengenai rasio likuiditas terhadap arus kas setiap tahunya dapat meningkat karna kas merupakan unsur aktiva yang paling lancar atau dengan kata lain kas merupakan modal kerja yang paling likuid, sehingga dengan ketersediaan kas yang cukup maka perusahaan tidak akan kesulitan dalam memenuhi yang jatuh tempo. Berkaitan dengan likuiditas perusahaan, arus kas memberikan imformasi bagi manajer mengenai kesanggupan perusahaan mampu memenuhi kewajiban jangka pendeknya yang jatuh tempo. Berdasrkan uraian diatas, maka penulis memilih judul "Analisis Rasio Likuditas Barbasis Arus Kas pada PT. Menara Phinisi Hotelindo di Kota Makassar"

\section{METODE PENELITIAN}

Jenis penelitian ini adalah penelitian deskriptif kuantiatif, hal ini dikarenakan fakta yang diteliti dilapangan dilakukan dengan menggunakan sistem observasi wawancara dan dokumentasi. Penelitian ini dilakukan di PT. Menara Phinisi Hotelindo jalan Tanjung Bunga No. 701 kota Makassar, adapun waktu penelitian diperkirakan kurang lebih 2 (dua) bulan mulai bulan April sampai Juni 2018. Agar data yang diperlukan dalam penelitian ini dapat diukur, maka dikemukakan pengertian terhadap variabel yang akan diukur sebagai berikut :

a. Laporan Keuangan

Laporan keuangan dibuat oleh pihak manajemen dengan tujuan untuk mempertanggung jawabkan tugas-tugas yang dibebankan kepadanya oleh para pemilik perusahaan. Laporan keuangan dapat digunakan untuk memenuhi tujuan lain misalnya sebagai laporan kepada pihak-pihak diluar perusahaan. 
Jurnal Ekonomi Balance Fakultas Ekonomi Dan Bisnis

Volume 12 No 2 Tahun 2016

b. Rasio Likuiditas

Rasio likuiditas menunjukkan kemampuan perusahaan dalam memenuhi kewajiban jangka pendeknya seperti melunasi utangnya yang jatuh tempo dalam jangka pendek.

c. Arus Kas

Arus kas adalah arus kas masuk (cash inflow) dan arus kas keluar (cash outflow). Pengertian arus kas masuk (cash inflow) adalah sumber-sumber dari mana arus kas diperoleh sedangkan arus kas keluar (cash outflow) adalah kebutuhan kas untuk pembayaran-pembayaran.

Untuk melengkapi data yang digunakan dalam pembahasan ini maka penulis memperoleh data yang bersumber dari peuahaan, yaitu; Data Primer yaitu data yang diperoleh secara langsun dari PT. Menara Phinisi Hotelindo kota Makassar melalui pengamatan dan wawancara (interview) mengenai keadaan Colonial Hotel dan Data Sekunder yaitu data yang diperoleh dari referensi baik berupa artikel, serta catatancatatan, laporan-laporan maupun arsip-arsip resmi dan dokumen-dokumen yang ada kaitannya dengan masalah penelitian.

Dalam penelitian ini metode pengumpulan data yang digunakan adalah Penelitian pustaka (library research), yaitu pengumpulan data teoritis dengan cara menelaah berbagai literature dan referensi pustaka yang dibutuhkan dan Penelitian lapangan (Field Research), yaitu teknik penelitian yang dilakukan dengan jalan melakukan langsung dilokasi penelitian dengan menempuh cara sebagai berikut . Observasi yaitu cara pengumpulan data dengan pengamatan terhadap objek yang diteliti dalam hal ini rasio Likuiditas dan arus kas. Interview (Wawancara) yaitu pengumpulan data secara langsung dalam bentuk Tanya jawab dengan responden yang ada hubungannya dengan masalah yang diteliti. Dokumentasi yaitu teknik pengumpulan data melalui dokumen-dokumen mengenai data yang dibutuhkan dalam suatu penelitian, dalam hal ini data yang akan diperoleh secara dokumentasi yang ada di perusahaan yang menjadi objek penelitian adalah data mengenai rasio Likuiditas dan arus kas pada PT. Menara Phinisi Hotelindo.

1. Pedoman observasi

Pedoman observasi digunakan agar peneliti dapat melakukan pengamatan sesuai dengan penelitian. 
Jurnal Ekonomi Balance Fakultas Ekonomi Dan Bisnis

Volume 12 No 2 Tahun 2016

2. Pedoman wawancara

Pedoman wawancara digunakan agar agar wawancara tidak menyimpan dari tujuan penelitian. Pedoman ini disusun tidak hanya berdasarkan tujuan penelitian, tetapi juga berdasarkan teori yang berkaitan dengan masalah yang diteliti.

3. Pedoman Dokumentasi

Pedoman dokumentasi digunakan untuk memperkuat data hasil wawancara dan obsevasi sehingga data yang dihasilkan akan lebih terpercaya.

\section{Metode Analisis}

Penelitian ini memakai analisis deskriptif kuantitatif, metode studi kasus bersifat menggambarkan rasio likuiditas dan arus kas pada PT. Menara Phinisi Hotelindo kota Makassar. Berdasarkan permasalahan yang ada maka langkah dalam teknik analisis penelitian ini adalah menganalisis rasio likuiditas berbasis arus kas pada PT. Menara Phinisi Hotelindo kota Makassar.

\section{HASIL DAN PEMBAHASAN}

\section{Analisis Rasio Likuiditas}

Rasio likuiditas adalah kemampuan perusahaan untuk memenuhi kewajibannya yang jatuh tempo dalam waktu dekat. Adapun posisi perusahaan memberikan indicator kemampuan untuk membayar utang jangka pendeknya perusahaan dan efesiensi operasi manajemen saat ini. Rasio likuiditas merupakan suatu alat analisis yang digunakan suatu alat oleh perusahaan untuk menilai kinerja keuangan berdasarkan data perbandingan masing-masing pos yang terdapat di laporan neraca, rugi/laba, dan arus kas dalam periode tertentu rasio likuiditas bertujuan untuk mengukurkemampuan suatu perusahaan untuk memenuhi kewajiban keuangannya yang harus segera dipenuhi (jangka pendek) perusahaan yang mampu untuk memenuhi kewajibanya disebut likuid, tapi jika perusahaan tidak dapat memenuhi kewajinbannya maka kinerja perusahaan kurang maksimal atau kurang bagus.

Perkembangan rasio likuiditas PT. Menara Phinisi Hotelindo tahun 2015-2017 dapat dihitung melalui neraca yang sudah disusun oleh bagian staf keuangan PT. 
Jurnal Ekonomi Balance Fakultas Ekonomi Dan Bisnis

Volume 12 No 2 Tahun 2016

Menara Phinisi Hotelindo Berikut Laporan Neraca yang dapat dilihat pada tabel 1 dan dapat dihitung dengan menggunakan rasio likuiditas.

\section{Rasio likuiditas meliputi :}

\section{a. Current Ratio}

Yaitu meliputi kemampuan aktiva lanca perusahaan dalam memenuhi kewajiban jangka pendek dengan aktiva lancar. Rasio yang paling banyak dipakai untuk mengukur likuiditas suatu perusahaan adalah current ratio . sering dikatakan bahwa suatu perusahaan adalah likuid apabila current ratio lebih besar dari satu (ini terjadi apabila aktiva lancar lebih besar dari pada kewajiban lancar). Secara umum hal tersebut dapat dikatakan benar akan tetapi jawaban yang paling tepat adalah belum tentu sebab sangat tergantung dari kualitas aktiva lancar dan kewajiban lancar yang dimaksud dari hasil perhitungan dapat terlihat bahwa dari tahun 2015 sampai dengan tahun 2017 nilai current ratio PT. Menara Phinisi Hotelindo mengalami kenaikan dengan nilai sebesar 1,31 atau $131 \%$ nilai tersebut diperoleh dari hasil perhitungan current ratio yaitu:

$$
\frac{\text { aktiva Lancar (Current Asset) }}{\text { Utang Lancar (Current Liabilities) }} \times 100 \%=\frac{636.111 .615}{485.279 .816} \times 100 \%=1,31
$$

Nilai ini bisa diinterpretasikan bahwa untuk setiap Rp 1,00 kewajiban lancar dijamin atau ditanggung oleh $\mathrm{Rp}$ 1,31 aktiva lancar hal ini menunjukkan di atas 1:3 dan nilai current ratio tertinggi terjadi pada tahun 2017 yaitu sebesar 1,35 atau 135\% yang diperoleh dari hasil perhitungan yaitu:

$$
\frac{\text { aktiva Lancar (Current Asset) }}{\text { Utang Lancar (Current Liabilities) }} \times 100 \%=\frac{654.999 .320}{483.349 .963} \times 100 \%=1,35
$$

Yang artinya setiap Rp 1,00 kewajiban lancar dijamin atau ditanggung oleh $\mathrm{Rp} \mathrm{1,35}$ aktiva lancar. Hal ini menunjukan bahwa PT.Menara Phinisi Hoteindo memiliki kemampuan untuk membayar kewajiban janga pendeknya. Karena nilai rasio likuiditasnya berada diatas 1:1 Penurunan yang sagat signifikan terjadi pada tahun 2015 dimna mengalami penurunan sebesar 1,03 dibandingkan dengan nilai current ratio pada tahun 201 . Hal ini disebabkan karna terjadi peningkatan pada kewajiban jangka pendeknya yaitu (terpisahnya biaya pengurus dan pegawai) sehingga terjadinya penurunan. Dalam komponen komponen kewajiban lancar (current ratio) yang semula sebesar 636.111.615 menjadi 654.999.320. 
Jurnal Ekonomi Balance Fakultas Ekonomi Dan Bisnis

Volume 12 No 2 Tahun 2016

Walaupun demikian, nilai current ratio pada PT. Menara Phinisi Hotelindo dikatakan baik karena nilai rasio likuiditasnya berada di atas 1 . Semakin tinggi current ratio seharusnya semakin besar kemampuan perusahaan untuk membayar kewajiban jangka pendek. Tetapi current ratio yang terlalu tinggi menunjukan manajemen yang buruk atas sumber likuiditas atau pengelolaan aktiva lancar kurang bagus karena masih banyak aktiva yang menganggur.

\section{b. Cash Rasio}

Kita tau bahwa aktiva lancar terdiri dari aktiva yang dapat dikomversikan dalam bentuk tunai kas merupakan elemen lancar yang paling tinggi baik likuiditasnya karena semakin banyak uang kas yang tersedia dalam perusahaan semakin baik sebab keperluan jangka pendek dapat pula berguna untuk menjaga pada keperluan yang mendesak. Semakin besar komposisi pos ini berarti semakin likuid suatu perusahaan. Maka dengan hal analisis rasio likuiditas Perusahaan, disamping current ratio, orang sering menggunakan cash ratio untuk mengukur jaminan yang diberikan oleh pos "tunai" dan surat-surat berharga terhadap kewajiban lancar.

Cash ratio mengukur kemampuan perusahaan dalam memenuhi kewajiban jangka pendek dengan cash dan surat-surat berharga yang dimiliki dan hasil perhitungan yang diperoleh cash ratio tertinggi yaitu pada tahun 2016 sebesar 0,16 atau $16 \%$ dimana nilai tersebut diperoleh dari hasil perhitungan yaitu:

$$
\frac{\text { Kas }(\text { Cash })+\text { Bank }}{\text { Utang Lancar }(\text { Carrent Liabilitas })} \times 100 \%=\frac{21.431 .400+52.727 .046}{485.279 .816} \times 100 \%=0,15
$$

Yang diartikan bahwa untuk setiap Rp 1,00 kewajiban lancar dijamin atau ditanggung oleh $\mathrm{Rp}$ 0,15 aktiva lancar. Sedangkan cash ratio yang terendah adalah pada tahun 2017 yang diperoleh dari hasil perhitungan yaitu:

$$
\frac{\text { Kas }(\text { Cash })+\text { Bank }}{\text { Utang Lancar }(\text { Carrent Liabilitas })} \times 100 \%=\frac{23.152 .047+33.992 .292}{483.349 .963} \times 100 \%=0,11
$$

Yang berarti setiap Rp 1,00 kewajiban lancar dijamin atau ditanggung oleh kas 0,11 aktiva lancar. Maka perusahaan ini dikatakan ilikuid. Untuk tahun 2015 nilai cash ratio menunjukan penurunan bukan berarti PT. Menara Phinisi Hotelindo kurang baik tetapi karena nilai cash rationya berada dibawah 1,00 dan dapat dianggap ilikuid. 
Jurnal Ekonomi Balance Fakultas Ekonomi Dan Bisnis

Volume 12 No 2 Tahun 2016

\section{c. Quick Ratio}

kualitas dan komposisi setiap barang (inventory). Dua pos terbesar dari aktva lancar umumya adalah persediaan barang dan piutang dagang. Dengan demikian, pos inventory ini sangat mempengaruhi likuid suatu perusahaan. Maka dengan hal tersebut dalam perhitungan rasio likuiditas orang sering mengeluarkan persediaan barang dari kelkulasi Rasio seperti ini sering disebut quick ratio. Quick ratio mengukur kemampuan aktiva lancar dikurangi persediaan dibagi dengan utang lancar dari hasil perhitungan diperoleh quick ratio tertinggi adalah pada tahun 2016 sebesar 0,20 atau 20\% dimana nilai tersebut diperoleh dari hasil perhitungan Quick ratio yaitu:

$$
\frac{\text { Aktiva Lancar-Persediaan }}{\text { Utang Lancar (Carrent Liability) }} \times 100 \%=\frac{636 . .111 .615-538.755 .141}{485.279 .816} \times 100 \%=0,20
$$

Yang diartikan bahwa untuk setiap Rp 1,00 hutang lancar dijamin oleh aktiva lancar selain persediaan sebesar $\mathrm{Rp}$ 0,20 untuk prinsip kehati-hatian, maka besarnya Quick ratio yang terendah adalah pada tahun 2017 sebersar 0,16 yang diperoleh dari hasil perhitungan yaitu:

$$
\frac{\text { Aktiva Lancar-Persediaan }}{\text { Utang Lancar }(\text { Carrent Liability })} \times 100 \%=\frac{654.999 .320-574.095 .347}{483.349 .963} \times 100 \%=0,16
$$

Yang berarti Rp kewajiban lancar dijamin atau ditanggung dengan 0,16 aktiva lancar dan persediaan. Nilai quick ratio PT. Menara Phinisi Hotelindo pada tahun 2016 dikatakan bahwa perusahaan tidak mampu untuk membayar kewajiban jangka pendeknya karena nilai rasio likuiditasnya berda dibawah 1:1

Nilai quick ratio PT. Menara Phinisi Hotelindo pada tahun 2015 dapat dikatan kurang baik karena besarnya berada dibawa 1;1 hal ini menunjukan bahwa PT. Menara Phinisi Hotelindo tdak memiliki kemampuan untuk membayar jangka pendeknya maka dianggap ilikuid. Laporan arus kas yang disusun oleh PT Menara Phinisi Hotelindo yang dilakukan dalam menyusun laporan arus kas adalah membuat laporan laba rugi untuk 3 tahun yaitu tahun 2015, 2016 dan tahun 2017. Pada tahap berikutnya adalah menyusun neraca tahun 2015, 2016 dan tahun 2017. Peneliti menyusun laporan arus kas untuk tahun 2017 dengan membandingkan tiga neraca tahun 2015 sampai tahun 2017 dan juga menggunakan laporan laba rugi per 
Jurnal Ekonomi Balance Fakultas Ekonomi Dan Bisnis

Volume 12 No 2 Tahun 2016

31 Desember 2015. Berdasarkan laporan-laporan diatas akan dapat menggambarkan perubahan masing-masing elemen dalam neraca dan laporan laba rugi dan selanjutnya disusun laporan arus kas tahun 2017.

Pada tahun 2017 total sumber kas PT Menara Phinisi Hotelindo (Colonial Hotel) adalah sebesar Rp 13.140.824.418 (sumber kas yang bersumber dari aktivitas operasi dan pendanaan) dan jumlah akhir penggunaan kas adalah sebesar Rp 3.836.180 (penggunaan kas bersumber dari aktivitas operasi dan pendanaan). Pada penjelasan berikut dibawah ini dibuat perhitungan dan penjelasan komposisi kas yaitu sumber dan penggunaan kas pada tahun 2017, adalah sebagai berikut:

1) Arus Kas dari Aktivitas Operasi Tahun 2017 Jumlah sumber-sumber kas yang bersumber dari aktivitas operasi dihitung sebagai berikut:

Jumlah Laba Bersih

Rp. 5.554.130.338

Penyusutan Aktiva Tetap

Rp. 4.470 .605 .885

Jika dihitung jumlah presentasi masing-masing sumber kas terhadap total sumber kas adalah sebagai berikut:

$$
\begin{array}{ll}
\text { Laba Bersih } & =\frac{5.554 .130 .338}{13.140 .824 .418} \times 100 \%=42,62 \% \\
\text { Penyusutan Aktiva Tetap } & =\frac{4.470 .605 .885}{13.140 .824 .418} \times 100 \%=34,02 \%
\end{array}
$$

Berdasarkan hasil perhitungan diatas sumber kas yang terbesar adalah dari aktivitas operasi yaitu sebesar $42,62 \%$ sedangkan penyusutan aktiva hanya mampu menyumbang sebesar $34,02 \%$.

2) Arus Kas dari Aktivitas Investasi Sumber kas dari aktivitas investasi pada PT. Menara Phinisi Hotelindo tidak ada aktivitas penambahan dana. Total penggunaan kas untuk aktivitas investasi adalah sebagai berikut:

Pembelian

Pembayaran hutang

Pembayaran gaji

Biaya penjualan

Biaya adminitrasi

Drapping pusat
Rp. 7.482.192.696

Rp. 4.035.346.965

Rp. 5.094.011.708

Rp. 7.700 .365

Rp. 5.049.247

Rp. 7.012.150.000 
Jurnal Ekonomi Balance Fakultas Ekonomi Dan Bisnis

Volume 12 No 2 Tahun 2016

Jika dihitung jumlah presentasi masing-masing sumber kas terhadap total

$$
\text { sumber kas adalah }=\frac{23.636 .450 .981}{13.140 .824 .418} \times 100 \%=179,87 \%
$$

Pembelian, pembayaran hutang, pembayaran gaji, biaya penjualan,biaya adminitrasi dan drapping pusat pada tahun 2017 sebesar 179,87\% dengan demikian perusahaan harus mampu menghemat pembelian kendaraan dan pemeliharaan untuk investasi dimasa yang akan datang karena hal ini akan mengakibatkan harta perusahaan akan berkurang.

3) Arus Kas dari Aktivitas Pendanaan Tahun 2017 Sumber penggunaan kas dari aktivitas pendanaan pada tahun 2015, tahun 2016 dan tahun 2017 adalah bersumber dari penambahan modal disetor. Pada tahun 2017 mengalami peningkatan sebesar Rp. 2.920.680.504 besaran prosentase terhadap total sumber kas dari aktivitas pendanaan adalah:

$$
=\frac{2.920 .680 .504}{13.140 .824 .418} \times 100 \%=16,10 \%
$$

Berdasarkan perhitungan keseluruhan sumber kas yang tertinggi adalah dari hasil aktivitas operasi yaitu laba bersih sebesar $42.62 \%$ dari total keseluruhan sumber kas. Penggunaan kas yang terbesar untuk aktivitas pendanaan yaitu pembayaran prive sebesar 179,87\%. Berdasarkan perhitungan secara keseluruhan laporan arus kas, dapat disimpulkan bahwa aktivitas perusahaan adalah baik. Hal ini dapat dibuktikan bahwa sumber kas yang terbesar berasal dari aktivitas operasi yaitu laba bersih yang merupakan sumber kas yang paling utama bagi perusahaan yang "Well Finance". 
Jurnal Ekonomi Balance Fakultas Ekonomi Dan Bisnis

Volume 12 No 2 Tahun 2016

\section{PENUTUP}

\section{Simpulan}

Penelitian ini bertujuan untuk mengetahui analisis rasio likuiditas berbasis arus kas pada PT. Menara Phinisi Hotelindo dikota Makassar. Berdasarkan rumusan masalah dalam penelitian ini maka, analisis data yang telah dilakukan dan pembahasan yang telah dikemukakan pada bab sebelumnya, maka dapat ditarik kesimpulan. Dengan demikian dapat disimpulkan bahwa dengan melakukan analisis laporan arus kas pada suatu perusahaan dapat ditentukan tingkat likuiditasnya. Hal ini sangat berguna bagi perusahaan dan invenstor atau kreditor untuk menilai kemampuan perusahaan dalam memenuhi kewajiban lancarnya dengan menggunakan aktiva lancar dan kas yang tersedia yang perolehanya berasal dari aktivitas operasi dan invenstasi serta dapat diketahui untuk apa saja kas tersebut digunakan.

\section{Saran}

Berdasarkan simpulan yang dikemukakan diatas, penulis mencoba memberikan saran-saran yang diharapkan dapat bermamfaat bagi PT. Menara Phinisi Hotelindo dikota Makassar, adapun saran-saran tersebut adalah:

1. Bagi PT Menara Phinisi Hotelindo kota Makassar, diharapkan dapat mempertahankan pengelolaan kas yang cukup baik. Arus kas harus selalu mendapatkan perhatian lebih dari manajemen perusahaan, karena arus kas merupakan jiwa (lifeblood) bagi perusahaan dan fundamental bagi eksistensi sebuah perusahaan. Dengan dana kas yang cukup besar

2. Bagi peneliti selanjutnya, disarankan untuk meneliti lebih lanjut masalah likuiditas perusahaan perusahaan dengan menggunakan rasio likuiditas, mengingat dalam penelitian saat ini masih banyak kekurangan. 
Jurnal Ekonomi Balance Fakultas Ekonomi Dan Bisnis

Volume 12 No 2 Tahun 2016

\section{DAFTAR PUSTAKA}

Ambari, S. 2014. Sekolah Tinggi Ilmu Ekonomi Indonesia Surabaya. Rasio Keuangan Berbasis Akrual Dan Berbasis Kas Untuk Memprediksi Financial Distress Pada Perusahaan Manufaktur Yang Terdaftar Di Bursa Efek Indonesia. (Online). Vol. 3 No. 12. (http://ejourna.estesia.ac.id, diakses 7 Maret 2018)

Fajar, K. A. 2015. Pengaruh Rasio Pofitabilitas dan Likuiditas Terhadap Peningkatan Laba Pada PT. Semen Tonasa periode 2009-2013. Program S1 Fakultas Ekonomi dan Bisnis Universitas Muhammadiyah Makassar.

Hariah. 2017. Laporan Arus Kas. (Online). Tersedia: https://dosenakuntansi.com/laporan-arus-kas.

Harahap, 2010. Analisis laporan keuangan, Cet 3, edisi 1, Jakarta : penerbit raja grafindo persada

Indrani, D. 2017. Fakultas Ekonomi dan Bisnis Pengaruh Perputaran Piutan dan Arus Kas Terhadap Likuiditas pada PT. Astra Internasional TBK. (online). Vol. 5 No. 1 (http://media.neliti.com, diakses 7 Maret 2018)

Kasmir. 2013. Pengantar manajemen keungan Cet 3. Jakarta: Kharisma putra Utama.

Kasmir. 2014. Analisis laporan keuangan Cet 7. Jakarta: rajawali pers.

Machdar, N. M. 2013. Institut Teknologi dan Bisnis Kalbe, Jakarta. Pengaruh Likuiditas dan Laba Terhadap Prediksi Arus Kas (Online). Vol. 18 No. 2. (http://researc.kalbis.ac.id, diakses 7 Maret 2018)

Martono, 2004, metodologi penelitian pendidikan, Jakarta: rineka cipta. dan harjito agus, D, 2007, manajemen keungan, Yogyakarta: penerbit ekonis ia.

Munawir, S. 2007. Analisis laporankeuangan. Edisi keempat, Jakarta:liberty. 
Jurnal Ekonomi Balance Fakultas Ekonomi Dan Bisnis

Volume 12 No 2 Tahun 2016

Purnomo, H. 2014. Dosen Fakultas Ekonomi Universitas Merdeka Madiun. Kajian Pengaruh Arus Kas Terhadap Likuiditas (Studi Kasus Pada Laporan Tahunan Bpr Arta Kencana Madiun). (Online). Vol. 3. No. 2 (http://unmermadium.ac.id, diakses 7 Maret 2018)

Roman, T. K. 2013. Universitas Negeri Padang. Pengaruh Kemampuan pediktif Laba dan Arus Kas Operasi dalam Memprediksi Arus Kas Operasi Masa depan (Studi Empiris pada Perusahaan Property dan Real Estate yang Terdaftar di Bursa Efek Indonesia). (online). Vol 1. No.3. (http://ejournal.unp.ac.id, diakses 7 Maret 2018)

Syafri, S. H. 2014. Analisis kritis atas laporan keuangan. Cet 11. Jakarta rajawali pers.

Sutarjo, Tui, 2013. Proposal kelayakan usaha UMKM untuk Perbankan. Cet 1, Yogyakarta.

Toto Prihadi, 2008-2009, 7 analisis rasio keuangan, Jakarta: penerbit PPM 